\title{
Using Hybrid Method in Selecting Timber Factory Location
}

\section{Primjena hibridnog postupka pri odabiru lokacije za drvoprerađivački pogon}

\author{
Preliminary paper • Prethodno priopćenje \\ Received-prispjelo: 9. 6. 2017. \\ Accepted-prihvaćeno: 13. 6. 2018. \\ UDK: $630 * 832.11$ \\ doi:10.5552/drind.2018.1736
}

\begin{abstract}
The selection of location is vital for a timber factory to keep on functioning. It is a significant decision during the setup of a business and the preparation of projects. Therefore, dual scaling method often used for selecting the timber factory location and Analytic Hierarchy Process (AHP) have been used in this study. While the AHP method and the double weighing method were previously used separately, the aim of this study was to use these two studies together in order to obtain more reliable results. For this purpose, in the Western Black Sea region of Turkey, five different candidate cities were selected for the establishment of a factory site for timber production: Bartin, Bolu, Kastamonu, Karabük and Zonguldak. At the same time, a total of ten factors including raw materials, labor, market, construction costs, energy and fuel, water, transportation, tax, security and social environment were determined. As a result of the study, the hybrid method, which is based on the average of both methods, yielded more reliable results.
\end{abstract}

Keywords: timber factory location, Dual Scaling, Analytic Hierarchy Process

SAŽETAK • Odabir lokacije za drvoprerađivački pogon vrlo je važan činitelj održivosti njegova poslovanja $i$ jedna od najvažnijih odluka pri pokretanju poslovanja i pripremi projekta. U radu je predstavljena hibridna metoda odlučivanja koja je kombinacija metode dvostrukog skaliranja, često korištene za odabir lokacije pogona za preradu drva, i metode analitičkoga hijerarhijskog procesa (AHP metoda). Dosada su AHP metoda i metoda dvostrukog skaliranja primjenjivane zasebno, a cilj je ovog rada povećati pouzdanost rezultata odlučivanja primjenom obje metode zajedno. S tim je ciljem u regiji Zapadno Crno more u Turskoj identificirano pet lokacija za pokretanje drvoprerađivačke proizvodnje: gradovi Bartin, Bolu, Kastamonu, Karabük i Zonguldak. Istodobno je postavljeno deset kriterija koji su obuhvatili sirovinu, radnu snagu, tržište, troškove izgradnje, energiju i gorivo, vodu, transport, porez, sigurnost i društveno okružje. Rezultat studije pokazao je da hibridna metoda, koja se temelji na srednjoj vrijednosti obiju metoda, daje pouzdanije rezultate nego svaka od tih metoda zasebno.

Ključne riječi: lokacija drvoprerađivačkog pogona, metoda dvostrukog skaliranja, metoda analitičkoga hijerarhijskog procesa

\section{INTRODUCTION}

\section{UVOD}

Business location is generally the geographical place where the organization provides the main services. The location for a manufacturing business can be defined as the most suitable place for carrying out the main functions such as provision, production, storage and distribution, and the related economic purposes. Location is a compulsory life space for an organization to go on running and develop. The most suitable

\footnotetext{
${ }^{1}$ Author is associated professor at Bartın University, Department of Management Information Systems, Bartin, Turkey.

${ }^{1}$ Autor je izvanredni profesor Odjela za upravljanje informacijskim sustavima, Sveučilište u Bartinu, Bartin, Turska.
} 
location for an economic business is the place where it can provide productive services at minimum cost and maximum profit after being established. The most suitable locations for the businesses, whose main aim is to prosper and bring benefit, are the places where they can fulfill these aims (Barutçugil, 1988).

The selected location is, in strict sense, "the place where business production activities are carried out". In broad sense, it is defined as "the most suitable place where the fundamental functions of a business, such as provision, production, storage and distribution and business income, will be at the maximum level and business cost at the minimum level, meaning that the business will be able to meet the necessary conditions for reaching its goals"; "the place meeting most appropriately the necessary technical and economic conditions for production compared to other locations"; "the place where the sum of expenses is at the lowest level"; "the place where there is no saving from the expenses and transportation costs from the selected location to a newly established location by means of replacement analysis" (İlter, 2001).

The selection of business location is a constant problem. New businesses are being established all the time. A specific industry can be completely replaced in $30-40$ years as a result of the fact that one of the factors affecting the selection of location loses its importance while another gains importance. A factory location satisfying the ideal conditions may lose this characteristic due to several reasons such as the changing environmental factors over time, and the changes in the place and scale of demand sources. Consequently, the convenience of the place, the change of location and other alternatives are the challenges that are frequently considered in every factory (Kobu, 1989).

The location selection is an important decision when establishing a business and developing projects. Thorough analysis is required before making a decision. Likewise, this decision is a factor that shapes the cost, profitability and running of a business organization in the future. Changing the location later is very hard and expensive. Therefore, the most affordable and profitable place should be selected among the alternatives while determining the location.

The location of an organization and its selection is one of the most important strategic issues in terms of investment decisions. The selection of location is not only important commercially but it also includes the aspects such as income distribution, local development differences, benefits from environmental factors and incentive schemes, exogeneity based on the gathering of business organizations in the same region that could be connected to each other.

There are several factors that influence the decision about the business location and that should be evaluated during this process. The factors to be taken into consideration for the selection of business location are the following:

- economic and quantitative factors,

- quality factors,

- non-economic factors.
Economic and quantitative factors could be listed as raw material and transportation, demand centers and product distribution, labor market, wage level and all other relevant costs. Quality factors include geodetic parameters such as educational opportunities, environmental awareness of the organization, labor force quality and substructure state. Non-economic factors are the parameters related to military, political and the firm's own strategy (Anonymous, 1985).

There are several basic principles for selecting the business location. These principles are as follows (Üçüncü, 2003):

- Requirements about factory location should be determined objectively and scientifically;

- Characteristics of the selected location that influence the factory services should be identified;

- Selected location studies should be conducted at specific stages and in proper order without mixing them; - Experts and organizations should be determined, whose experience and knowledge could be beneficial in every phase;

- The decision on selecting the location should be made after a comprehensive consideration and proper evaluation of the state of location factors;

- Comprehensive, suitable, complete and certain information should be obtained from various sources.

\section{MATERIALS AND METHOD}

2. MATERIJALI I METODE

Five different candidate cities, namely Bartın, Bolu, Kastamonu, Karabük and Zonguldak, have been determined in the Black Sea Region for selecting the location of a timber factory, which will produce annually $13.000 \mathrm{~m}^{3}$ of lumber (Figure 1).

Besides, ten factors in total have been determined such as Raw Material, Labor Force, Market, Construction Cost, Energy and Fuel, Water, Transportation, Tax, Security, Social Environment, all of which would affect the investment.

\subsection{Dual Scaling Method}

\subsection{Metoda dvostrukog skaliranja}

Importance scores are given to the factors affecting the selection of the location between 0 and 10 (it could be between 0 and 100 or 0 and 1) according to production efficiency and importance level. Similarly, the scores that candidate locations will be able to get from each factor range from 0 to 10 . The weighted scores that candidate locations will get from each factor are obtained by multiplying the importance scores and the scores of the candidate cities. The scores of candidate locations are added separately to each candidate location, and thus total scores are found. Total scores determine the evaluation order of the candidate locations. The candidate location having the highest total weight is selected as the right location (Üçüncü 2003).

\subsection{Analytic Hierarchy Process (AHP)}

2.2. Analitički hijerarhijski proces (AHP)

The Analytic Hierarchy Process (AHP) is a multicriteria decision making method that helps the decision- 


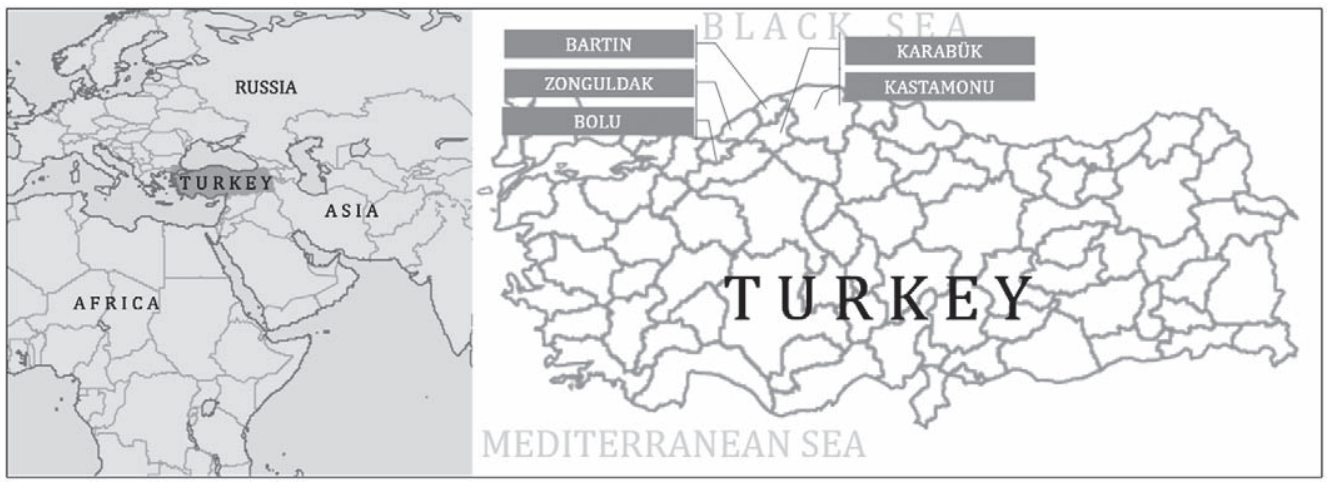

Figure 1 Candidate cities on the map

Slika 1. Prikaz potencijalnih lokacija (gradova) na karti

maker face a complex problem with multiple conflicting and subjective criteria (for example selecting a location or investment, project ranking, etc.). AHP is a mathematical method considering group and individual priorities, and evaluating the quantitative and qualitative variables together in the course of decision making. Several papers have addressed the AHP success stories in very different fields (Zahedi, 1986; Golden et al, 1989; Shim, 1989; Vargas, 1990; Saaty and Forman, 1992; Forman and Gass, 2001; Kumar and Vaidya, 2006; Ho, 2008; Liberatore and Nydick, 2008).

The use of personal judgment for decision making problems has increased on a remarkable scale recently. Efforts have been made to recognize specific decision making mechanisms considering the observations of the decision makers in different psychological and sociological situations through AHP. The aim of this method was to enable decision makers to make decisions more effectively (Saaty, 1980). This method has attracted considerable attention and has been applied for the solution of most decision making problems in real life.

The first step in AHP is to determine the factors and sub-factors in line with the purpose of the decision maker. Initially, the purpose is set in AHP, and the factors influencing the purpose in line with this purpose are tried to be determined. In this stage, a survey study and opinion of the experts in this area could be obtained and applied to specify all the factors influencing the purpose in line with this purpose.

Psychologists argue that it is easier and more accurate to express one's opinion on only two alternatives than simultaneously on all the alternatives. It also allows consistency and cross checking between different pairwise comparisons. AHP uses a ratio scale, which, contrary to methods using interval scales (Kainulainen et al., 2009), requires no units in the comparison. The judgement is a relative value or a quotient $a / b$ of two quantities $a$ and $b$ having the same units (intensity, meters, utility and so on). The decision-maker does not need to provide a numerical judgement; instead a relative verbal appreciation, more common in our daily lives, is sufficient.

Dual comparison decision matrixes are formed in order to determine the significance level between each other after specifying the purpose, factor and sub-factors. While forming these matrixes, 1-9 significance scale by Saaty (1990) is used. Provided that the decision made at the end of the study is influential for most people, dual comparison decision matrixes are formed by integrating the judgment of different people. A plenty of researchers recommend the use of geometric average method in this integration process so as to obtain consistent dual comparison matrixes (Tam and Tummala, 2001). 1-9 significance scale suggested by Saaty provides the best results. The other significance scales such as 1-5, 1-7, 1-15 and 1-20 fail to find the appropriate solution. The significance scale values and meanings are explained in Table 1 (Saaty, 1980). The formation of dual comparison decision matrixes is the most important stage of AHP. According to the data by dual comparison decision matrixes, the judgments are converted into a matrix in AHP. If $a_{i j}$ is indicated as dual comparison score of $i$. and $j$., $a_{i j}$ value is obtained from $1 / a_{i j}$ equivalence. This characteristic is called correspondence (Saaty, 1999). After creating dual comparison decision matrixes, the following step is to calculate the priorities or weight vectors. The method requires the normalization of the comparison matrix, adding the values in each column. The next step is to divide each cell by the total of the column. Based on this normalized matrix, the overall or final priorities are obtained by calculating the average value of each row. In the AHP, the pairwise comparisons in a judgment matrix are considered to be adequately consistent if the corresponding consistency ratio (CR) is less than $10 \%$ (Saaty, 1980). In the AHP, the consistency ratio is defined as $\mathrm{CR}$, where $\mathrm{CR}=\mathrm{CI} / \mathrm{RI}$. To calculate the consistency index (CI), the corresponding column value in the decision matrix is multiplied by the values of the priority vectors that have emerged. After this phase, CI value $(\lambda e n b-n) / n-1$ is found via the solution of the equations system. Consistency rate (CR) is obtained by dividing the obtained CI values by the Random Integrity Index. RI value takes different values according to the number " $n$ ". However, calculating the eigen values and eigen vectors of this equation system is very complicated and time-consuming especially for large-scale matrixes $(n>5)$. 
Table 1 Superiority values used in AHP Methodology

Tablica 1. Vrijednosti relativnih važnosti u AHP metodi

\begin{tabular}{|c|l|l|}
\hline $\begin{array}{c}\text { Value } \\
\text { Intenzitet } \\
\text { važnosti }\end{array}$ & Definition / Definicija & \multicolumn{1}{c|}{ Explanation / Objašnjenje } \\
\hline 1 & $\begin{array}{l}\text { Equal importance } \\
\text { jednako važno }\end{array}$ & $\begin{array}{l}\text { Two factors are equally important. } \\
\text { Dva kriterija ili alternative imaju jednaku važnost. }\end{array}$ \\
\hline 3 & $\begin{array}{l}\text { Moderate importance } \\
\text { umjereno važnije }\end{array}$ & $\begin{array}{l}\text { Experience and judgment slightly favor one over the other. } \\
\text { Na temelju iskustva i procjene daje se umjerena prednost jednom kriteriju ili alternativi } \\
\text { uodnosu prema drugome. }\end{array}$ \\
\hline 5 & $\begin{array}{l}\text { Strong importance } \\
\text { znatno važnije }\end{array}$ & $\begin{array}{l}\text { Experience and judgment strongly favor one over the other. } \\
\text { Na temelju iskustva i procjene daje se velika prednost jednom kriteriju ili alternativi u } \\
\text { odnosu prema drugome. }\end{array}$ \\
\hline 9 & $\begin{array}{l}\text { Very strong importance } \\
\text { izrazito važnije, } \\
\text { dokazano važnije }\end{array}$ & $\begin{array}{l}\text { One factor favors over another. } \\
\text { Jedan kriterij ili alternativa izrazito se favorizira u odnosu prema drugome. }\end{array}$ \\
\hline $\begin{array}{l}\text { Extreme importance } \\
\text { ekstremno važnije }\end{array}$ & $\begin{array}{l}\text { The evidence showing one factor favoring over the other has a high reliability. } \\
\text { Dokazi na osnovi kojih se favorizira jedan kriterij ili alternativa u odnosu prema } \\
\text { drugome potvrđeni su s najvećom uvjerljivošcu. }\end{array}$ \\
\hline $\begin{array}{l}\text { The values between two successive judgments to be used when compromise is } \\
\text { necessary. } \\
\text { Vrijednosti između dviju uzastopnih prosudbi koje će se primijeniti kada je potrebno } \\
\text { napraviti kompromis. }\end{array}$ \\
\hline
\end{tabular}

The methods, which are easier to calculate and will give approximate results instead of the above system of equations, are preferred in the implementation (Saaty, 2000). A common method used for calculating the priority vectors is this: Normalized matrix is found by dividing every column value into the related column sum separately, and every sequence value is averaged with reference to the normalized matrix, and these values are the importance weights found for each factor. The priority vector is formed via these weights.

Finally, the result matrix is found by multiplying weights vector and binary matrixes. Thus, the objective is accomplished by selecting the most suitable alternative for the criteria identified among the alternatives.

Data were obtained by conducting a questionnaire with 14 experts in the field. Those who deviated from these data have been eliminated. The average of the answers given by the remaining 11 experts was used in the study. The data of the work is also the actual data used in an investment project.

\subsection{Conversion of data appropriate for AHP} method

\subsection{Pretvorba podataka prikladnih za AHP metodu}

The data, which were obtained as a result of dual scaling and an algorithm developed in the study, are turned into data sets to be used by the AHP method. The formulas are the following:

$$
\begin{gathered}
t_{i j}=\frac{a_{i j}}{\operatorname{Mak}\left(a_{i j}\right)} \cdot 8+1 \\
z_{i j}=\frac{t_{i j}}{\operatorname{Min}\left(t_{i j}\right)}
\end{gathered}
$$

Where:

$a_{i j}$ - data set obtained via dual scaling $\operatorname{Mak}\left(a_{i j}\right)$ - the highest number in the data set $t_{i j}$ - normalized data for AHP
$\operatorname{Min}\left(t_{i j}\right)$ - the lowest number in the data set $z_{i j}$ - data used for AHP.

\section{RESULTS}

\section{REZULTATI}

The factors, determined beforehand for Timber Factory, should be weighted before dual scaling method. The loads of the necessary factors have been identified so as to determine the factory location during the installation of the timber factory (Table 2). The data were obtained by averaging the data recommended by 11 experts.

The data in the study are primarily evaluated in regard to Dual Scaling method. The results obtained via Dual Scaling method are presented below (Table 3 ). The data were obtained by averaging the data recommended by 11 experts.

The data sets are made usable for AHP by using normalization formulas developed in the following step (Table 4).

Table 2 Values of factors to be used in dual scaling method Tablica 2. Vrijednosti kriterija koji će se primijeniti u metodi dvostrukog skaliranja

\begin{tabular}{|c|l|c|}
\hline No & \multicolumn{1}{|c|}{ Factors / Kriteriji } & $\begin{array}{c}\text { Value } \\
\text { Vrijednost }\end{array}$ \\
\hline 1 & Raw material / sirovina & 10.0 \\
\hline 2 & Labor force / radna snaga & 8.0 \\
\hline 3 & Market / tržište & 9.5 \\
\hline 4 & Energy and fuel / energija i gorivo & 5.1 \\
\hline 5 & Social environment / društveno okružje & 3.3 \\
\hline 6 & Water / voda & 2.0 \\
\hline 7 & Tax / porez & 7.5 \\
\hline 8 & Construction cost / troškovi izgradnje & 7.3 \\
\hline 9 & Transportation / transport & 7.9 \\
\hline 10 & Security / sigurnost & 2.5 \\
\hline
\end{tabular}


Table 3 Coefficients and rough values of candidate cities by factors

Tablica 3. Koeficijenti i okvirne vrijednosti gradova kandidata s obzirom na zadane kriterije

\begin{tabular}{|c|c|c|c|c|c|c|c|c|c|c|c|c|}
\hline & \multirow{2}{*}{\begin{tabular}{|l} 
Factors / Kriteriji \\
Raw material / sirovina
\end{tabular}} & \multirow{2}{*}{$\begin{array}{c}\text { Value } \\
\text { Vrijed- } \\
\text { nost } \\
10.0\end{array}$} & \multicolumn{2}{|c|}{ BARTIN } & \multicolumn{2}{|c|}{ BOLU } & \multicolumn{2}{|c|}{$\begin{array}{l}\text { ZONGUL- } \\
\text { DAK }\end{array}$} & \multicolumn{2}{|c|}{ KARABÜK } & \multicolumn{2}{|c|}{$\begin{array}{l}\text { KASTA- } \\
\text { MONU }\end{array}$} \\
\hline & & & 8.3 & 83.00 & 9.3 & 93.00 & 8.1 & 81.00 & 7.5 & 75.00 & 8.8 & 88.00 \\
\hline 2 & Labor force / radna snaga & 8.0 & 5.0 & 40.00 & 8.7 & 69.6 & 8.5 & 68.00 & 6.8 & 54.40 & 7.4 & 59.2 \\
\hline 3 & Market / tržište & 9.5 & 7.0 & 66.50 & 8.9 & 84.55 & 7.1 & 67.45 & 6.4 & 60.80 & 7.1 & 67.45 \\
\hline 4 & Energy and fuel / energija i gorivo & 5.1 & 8.5 & 43.35 & 7.3 & 37.23 & 7.5 & 38.25 & 8.1 & 41.31 & 8.2 & 41.82 \\
\hline 5 & $\begin{array}{l}\text { Social environment } \\
\text { društveno okružje }\end{array}$ & 3.3 & 5.0 & 16.50 & 8.8 & 29.04 & 6.5 & 21.45 & 6.0 & 19.80 & 6.3 & 20.79 \\
\hline 6 & Water / voda & 2.0 & 7.2 & 14.40 & 9.1 & 18.20 & 7.3 & 14.60 & 7.6 & 15.20 & 9.0 & 18.00 \\
\hline 7 & Tax / porez & 7.5 & 8.9 & 66.75 & 7.2 & 54.00 & 7.3 & 54.75 & 7.9 & 59.25 & 8.1 & 60.75 \\
\hline 8 & $\begin{array}{l}\text { Construction cost } \\
\text { troškovi izgradnje }\end{array}$ & 7.3 & 5.1 & 37.23 & 8.6 & 62.78 & 4.5 & 32.85 & 8.1 & 59.13 & 8.0 & 58.40 \\
\hline 9 & Transportation / transport & 7.9 & 5.5 & 43.45 & 9.6 & 75.84 & 5.5 & 43.45 & 5.2 & 41.08 & 5.4 & 42.66 \\
\hline 10 & Security / sigurnost & 2.5 & 9.5 & 23.75 & 9.1 & 22.75 & 9.0 & 22.50 & 8.7 & 21.75 & 8.8 & 22.00 \\
\hline
\end{tabular}

Table 4 Conversion of data sets to data to be used by AHP

Tablica 4. Skupovi podataka pretvoreni u podatke kojima će se koristiti AHP metoda

\begin{tabular}{|c|l|c|c|c|c|c|}
\hline No & \multicolumn{1}{|c|}{ Factors / Kriteriji } & BARTIN & BOLU & ZONGULDAK & KARABÜK & KASTAMONU \\
\hline 1 & Raw material / sirovina & 3.07287 & 3.36538 & 3.15385 & 3.03714 & 3.39316 \\
\hline 2 & Labor force / radna snaga & 2.00405 & 3.17308 & 3.29060 & 2.78957 & 2.91453 \\
\hline 3 & Market / tržište & 2.65182 & 3.23718 & 2.81197 & 2.64810 & 2.81197 \\
\hline 4 & Energy and fuel / energija i gorivo & 3.13765 & 2.72436 & 2.94872 & 3.24934 & 3.18803 \\
\hline 5 & Social environment / društveno okružje & 2.00405 & 3.20513 & 2.60684 & 2.50663 & 2.53846 \\
\hline 6 & Water / voda & 2.71660 & 3.30128 & 2.88034 & 3.07250 & 3.46154 \\
\hline 7 & Tax / porez & 3.26721 & 2.69231 & 2.88034 & 3.17860 & 3.15385 \\
\hline 8 & Construction cost / troškovi izgradnje & 2.03644 & 3.14103 & 1.92308 & 3.24934 & 3.11966 \\
\hline 9 & Transportation / transport & 2.16599 & 3.46154 & 2.26496 & 2.22370 & 2.23077 \\
\hline 10 & Security / sigurnost & 3.46154 & 3.30128 & 3.46154 & 3.46154 & 3.39316 \\
\hline
\end{tabular}

Step 1:

The matrixes in Table 5 have been found as a result of forming the priority matrixes of the candidate cities for each factor.

\section{Step 2:}

The column values of every matrix are added up and they are divided into the data in that column (Table $6,7)$.

Table 5 Priority matrixes of candidate cities

Tablica 5. Prioritetne matrice gradova kandidata

\begin{tabular}{|l|c|c|c|c|c|}
\hline \multicolumn{1}{|c|}{$\begin{array}{c}\text { Raw material } \\
\text { Sirovina }\end{array}$} & BARTIN & BOLU & ZONGULDAK & KARABÜK & KASTAMONU \\
\hline BARTIN & 1.00000 & 0.91308 & 0.97433 & 1.01177 & 0.90561 \\
\hline BOLU & 1.09519 & 1.00000 & 1.06707 & 1.10808 & 0.99181 \\
\hline ZONGULDAK & 1.02635 & 0.93714 & 1.00000 & 1.03843 & 0.92947 \\
\hline KARABÜK & 0.98837 & 0.90246 & 0.96299 & 1.00000 & 0.89508 \\
\hline KASTAMONU & 1.10423 & 1.00825 & 1.07588 & 1.11722 & 1.00000 \\
\hline
\end{tabular}

\begin{tabular}{|l|c|c|c|c|c|}
\hline $\begin{array}{c}\text { Labor force } \\
\text { Radna snaga }\end{array}$ & $\mathbf{2 7 3 - 2 8 1}$ & BOLU & ZONGULDAK & KARABÜK & KASTAMONU \\
\hline BARTIN & 1.00000 & 0.63158 & 0.60902 & 0.71841 & 0.68761 \\
\hline BOLU & 1.58333 & 1.00000 & 0.96429 & 1.13748 & 1.08871 \\
\hline ZONGULDAK & 1.64198 & 1.03704 & 1.00000 & 1.17961 & 1.12903 \\
\hline KARABÜK & 1.39197 & 0.87914 & 0.84774 & 1.00000 & 0.95712 \\
\hline KASTAMONU & 1.45432 & 0.91852 & 0.88571 & 1.04480 & 1.00000 \\
\hline
\end{tabular}

\begin{tabular}{|l|c|c|c|c|c|}
\hline \multicolumn{1}{c|}{$\begin{array}{c}\text { Market } \\
\text { Tržište }\end{array}$} & BARTIN & BOLU & ZONGULDAK & KARABÜK & KASTAMONU \\
\hline BARTIN & 1.00000 & 0.81918 & 0.94305 & 1.00141 & 0.94305 \\
\hline BOLU & 1.22074 & 1.00000 & 1.15122 & 1.22245 & 1.15122 \\
\hline ZONGULDAK & 1.06039 & 0.86865 & 1.00000 & 1.06188 & 1.00000 \\
\hline KARABÜK & 0.99860 & 0.81803 & 0.94173 & 1.00000 & 0.94173 \\
\hline KASTAMONU & 1.06039 & 0.86865 & 1.00000 & 1.06188 & 1.00000 \\
\hline
\end{tabular}


Table 5 Priority matrixes of candidate cities

Tablica 5. Prioritetne matrice gradova kandidata

\begin{tabular}{|l|c|c|c|c|c|}
\hline $\begin{array}{c}\text { Energy and oil } \\
\text { Energija } \text { i gorivo }\end{array}$ & BARTIN & BOLU & ZONGULDAK & KARABÜK & KASTAMONU \\
\hline BARTIN & 1.00000 & 1.15170 & 1.06407 & 0.96563 & 0.98420 \\
\hline BOLU & 0.86828 & 1.00000 & 0.92391 & 0.83844 & 0.85456 \\
\hline ZONGULDAK & 0.93978 & 1.08235 & 1.00000 & 0.90748 & 0.92493 \\
\hline KARABÜK & 1.03560 & 1.19270 & 1.10195 & 1.00000 & 1.01923 \\
\hline KASTAMONU & 1.01606 & 1.17020 & 1.08116 & 0.98113 & 1.00000 \\
\hline
\end{tabular}

\begin{tabular}{|l|c|c|c|c|c|}
\hline $\begin{array}{c}\text { Social environment } \\
\text { Društveno okružje }\end{array}$ & BARTIN & BOLU & ZONGULDAK & KARABÜK & KASTAMONU \\
\hline BARTIN & 1.00000 & 0.62526 & 0.76877 & 0.79950 & 0.78947 \\
\hline BOLU & 1.59933 & 1.00000 & 1.22951 & 1.27866 & 1.26263 \\
\hline ZONGULDAK & 1.30079 & 0.81333 & 1.00000 & 1.03998 & 1.02694 \\
\hline KARABÜK & 1.25078 & 0.78207 & 0.96156 & 1.00000 & 0.98746 \\
\hline KASTAMONU & 1.26667 & 0.79200 & 0.97377 & 1.01270 & 1.00000 \\
\hline
\end{tabular}

\begin{tabular}{|l|c|c|c|c|c|}
\hline \multicolumn{1}{c|}{$\begin{array}{c}\text { Water } \\
\text { Voda }\end{array}$} & BARTIN & BOLU & ZONGULDAK & KARABÜK & KASTAMONU \\
\hline BARTIN & 1.00000 & 0.82289 & 0.94315 & 0.88417 & 0.78480 \\
\hline BOLU & 1.21523 & 1.00000 & 1.14614 & 1.07446 & 0.95370 \\
\hline ZONGULDAK & 1.06027 & 0.87249 & 1.00000 & 0.93746 & 0.83210 \\
\hline KARABÜK & 1.13101 & 0.93070 & 1.06671 & 1.00000 & 0.88761 \\
\hline KASTAMONU & 1.27422 & 1.04854 & 1.20178 & 1.12662 & 1.00000 \\
\hline
\end{tabular}

\begin{tabular}{|l|c|c|c|c|c|}
\hline \multicolumn{1}{c|}{$\begin{array}{c}\text { Tax } \\
\text { Porez }\end{array}$} & BARTIN & BOLU & ZONGULDAK & KARABÜK & KASTAMONU \\
\hline BARTIN & 1.00000 & 1.21353 & 1.13431 & 1.02787 & 1.03594 \\
\hline BOLU & 0.82404 & 1.00000 & 0.93472 & 0.84701 & 0.85366 \\
\hline ZONGULDAK & 0.88159 & 1.06984 & 1.00000 & 0.90617 & 0.91328 \\
\hline KARABÜK & 0.97288 & 1.18062 & 1.10355 & 1.00000 & 1.00785 \\
\hline KASTAMONU & 0.96530 & 1.17143 & 1.09496 & 0.99221 & 1.00000 \\
\hline
\end{tabular}

\begin{tabular}{|l|c|c|c|c|c|}
\hline $\begin{array}{l}\text { Construction cost } \\
\text { Troškovi izgradnje }\end{array}$ & BARTIN & BOLU & ZONGULDAK & KARABÜK & KASTAMONU \\
\hline BARTIN & 1.00000 & 0.64834 & 1.05895 & 0.62672 & 0.65278 \\
\hline BOLU & 1.54241 & 1.00000 & 1.63333 & 0.96667 & 1.00685 \\
\hline ZONGULDAK & 0.94433 & 0.61224 & 1.00000 & 0.59184 & 0.61644 \\
\hline KARABÜK & 1.59560 & 1.03448 & 1.68966 & 1.00000 & 1.04157 \\
\hline KASTAMONU & 1.53192 & 0.99320 & 1.62222 & 0.96009 & 1.00000 \\
\hline
\end{tabular}

\begin{tabular}{|l|c|c|c|c|c|}
\hline $\begin{array}{c}\text { Transportation } \\
\text { Transport }\end{array}$ & BARTIN & BOLU & ZONGULDAK & KARABÜK & KASTAMONU \\
\hline BARTIN & 1.00000 & 0.62573 & 0.95631 & 0.97405 & 0.97096 \\
\hline BOLU & 1.59813 & 1.00000 & 1.52830 & 1.55666 & 1.55172 \\
\hline ZONGULDAK & 1.04569 & 0.65432 & 1.00000 & 1.01856 & 1.01533 \\
\hline KARABÜK & 1.02664 & 0.64240 & 0.98178 & 1.00000 & 0.99683 \\
\hline KASTAMONU & 1.02991 & 0.64444 & 0.98491 & 1.00318 & 1.00000 \\
\hline
\end{tabular}

\begin{tabular}{|l|c|c|c|c|c|}
\hline \multicolumn{1}{|c|}{$\begin{array}{c}\text { Security } \\
\text { Sigurnost }\end{array}$} & BARTIN & BOLU & ZONGULDAK & KARABÜK & KASTAMONU \\
\hline BARTIN & 1.00000 & 1.04854 & 1.00000 & 1.00000 & 1.02015 \\
\hline BOLU & 0.95370 & 1.00000 & 0.95370 & 0.95370 & 0.97292 \\
\hline ZONGULDAK & 1.00000 & 1.04854 & 1.00000 & 1.00000 & 1.02015 \\
\hline KARABÜK & 1.00000 & 1.04854 & 1.00000 & 1.00000 & 1.02015 \\
\hline KASTAMONU & 0.98025 & 1.02783 & 0.98025 & 0.98025 & 1.00000 \\
\hline
\end{tabular}

Step 3:

Necessary coefficients for raw material factor to be used in the main matrix are obtained by finding the line averages of these new values (Table 7).

The exact matrix is found as follows by repeating the same process for the other factors (Table 8).
After the matrix is found as a result of comparison between the factors among the candidate cities, a new matrix is similarly formed in the consequence of priority comparisons applied among the factors themselves (Table 9). 
Table 6 Summation of matrix columns of raw material factor

Tablica 6. Sažetak matričnih stupaca kriterija sirovine

\begin{tabular}{|l|c|c|c|c|c|}
\hline Raw material / Sirovina & BARTIN & BOLU & ZONGULDAK & KARABÜK & KASTAMONU \\
\hline BARTIN & 1.00000 & 0.91308 & 0.97433 & 1.01177 & 0.90561 \\
\hline BOLU & 1.09519 & 1.00000 & 1.06707 & 1.10808 & 0.99181 \\
\hline ZONGULDAK & 1.02635 & 0.93714 & 1.00000 & 1.03843 & 0.92947 \\
\hline KARABÜK & 0.98837 & 0.90246 & 0.96299 & 1.00000 & 0.89508 \\
\hline KASTAMONU & 1.10423 & 1.00825 & 1.07588 & 1.11722 & 1.00000 \\
\hline Total / Ukupno & 5.21414 & 4.76094 & 5.08027 & 5.27550 & 4.72197 \\
\hline
\end{tabular}

Table 7 The average of matrix lines of raw material factor

Tablica 7. Proračun srednjih vrijednosti matričnih linija za kriterij sirovine

\begin{tabular}{|l|c|c|c|c|c|c|}
\hline $\begin{array}{c}\text { Raw material } \\
\text { Sirovina }\end{array}$ & BARTIN & BOLU & ZONGULDAK & KARABÜK & KASTAMONU & $\begin{array}{c}\text { Raw material } \\
\text { Sirovina }\end{array}$ \\
\hline BARTIN & 0.191786 & 0.191786 & 0.191786 & 0.191786 & 0.191786 & 0.191786 \\
\hline BOLU & 0.210042 & 0.210042 & 0.210042 & 0.210042 & 0.210042 & 0.210042 \\
\hline ZONGULDAK & 0.196840 & 0.196840 & 0.196840 & 0.196840 & 0.196840 & 0.196840 \\
\hline KARABÜK & 0.189556 & 0.189556 & 0.189556 & 0.189556 & 0.189556 & 0.189556 \\
\hline KASTAMONU & 0.211776 & 0.211776 & 0.211776 & 0.211776 & 0.211776 & 0.211776 \\
\hline Total / Ukupno & 1.000000 & 1.000000 & 1.000000 & 1.000000 & 1.000000 & 1.000000 \\
\hline
\end{tabular}

Table 8 Values of factors for each candidate city

Tablica 8. Vrijednosti kriterija za svaki grad kandidat

\begin{tabular}{|l|c|c|c|c|c|}
\hline Factors / Kriteriji & BARTIN & BOLU & ZONGULDAK & KARABÜK & KASTAMONU \\
\hline Raw material / sirovina & 0.191786 & 0.210042 & 0.196840 & 0.189556 & 0.211776 \\
\hline Labor force / radna snaga & 0.141411 & 0.223900 & 0.232193 & 0.196839 & 0.205657 \\
\hline Market / tržište & 0.187262 & 0.228598 & 0.198571 & 0.186999 & 0.198571 \\
\hline Energy and fuel / energija i gorivo & 0.205773 & 0.178669 & 0.193383 & 0.213098 & 0.209077 \\
\hline Social environment / društveno okružje & 0.155822 & 0.249211 & 0.202692 & 0.194900 & 0.197375 \\
\hline Water / voda & 0.176034 & 0.213921 & 0.186644 & 0.199096 & 0.224305 \\
\hline Tax / porez & 0.215340 & 0.177449 & 0.189842 & 0.209500 & 0.207869 \\
\hline Construction cost / troškovi izgradnje & 0.151188 & 0.233195 & 0.142772 & 0.241236 & 0.231608 \\
\hline Transportation / transport & 0.175427 & 0.280356 & 0.183443 & 0.180101 & 0.180674 \\
\hline Security / sigurnost & 0.202677 & 0.193294 & 0.202677 & 0.202677 & 0.198674 \\
\hline
\end{tabular}

Table 9 Superiority matrix among factors

Tablica 9. Matrica superiornosti kriterija

\begin{tabular}{|l|c|c|c|c|c|c|c|c|c|c|}
\hline & $\begin{array}{c}\text { Raw } \\
\text { material } \\
\text { Sirovina }\end{array}$ & $\begin{array}{c}\text { Labor } \\
\text { force } \\
\text { Radna } \\
\text { snaga }\end{array}$ & $\begin{array}{c}\text { Market } \\
\text { Tržište }\end{array}$ & $\begin{array}{c}\text { Energy } \\
\text { and fuel } \\
\text { Energija } \\
\text { i gorivo }\end{array}$ & $\begin{array}{c}\text { Social } \\
\text { environ- } \\
\text { ment } \\
\text { Društ- } \\
\text { veno } \\
\text { okružje }\end{array}$ & $\begin{array}{c}\text { Water } \\
\text { Voda }\end{array}$ & $\begin{array}{c}\text { Tax } \\
\text { Porez }\end{array}$ & $\begin{array}{c}\text { Con- } \\
\text { struc- } \\
\text { tion cost } \\
\text { Troškovi } \\
\text { izgradnje }\end{array}$ & $\begin{array}{c}\text { Trans- } \\
\text { porta- } \\
\text { tion } \\
\text { Trans- } \\
\text { port }\end{array}$ & $\begin{array}{c}\text { Security } \\
\text { Sigur- } \\
\text { nost }\end{array}$ \\
\hline $\begin{array}{l}\text { Raw material } \\
\text { Sirovina }\end{array}$ & 1.00000 & 1.21622 & 1.04651 & 1.77165 & 2.47253 & 3.46154 & 1.28571 & 1.31579 & 1.22951 & 3.00000 \\
\hline $\begin{array}{l}\text { Labor force } \\
\text { Radna snaga }\end{array}$ & 0.82222 & 1.00000 & 0.86047 & 1.45669 & 2.03297 & 2.84615 & 1.05714 & 1.08187 & 1.01093 & 2.46667 \\
\hline Market / Tržište & 0.95556 & 1.16216 & 1.00000 & 1.69291 & 2.36264 & 3.30769 & 1.22857 & 1.25731 & 1.17486 & 2.86667 \\
\hline $\begin{array}{l}\text { Energy and fuel } \\
\text { Energija i gorivo }\end{array}$ & 0.56444 & 0.68649 & 0.59070 & 1.00000 & 1.39560 & 1.95385 & 0.72571 & 0.74269 & 0.69399 & 1.69333 \\
\hline $\begin{array}{l}\text { Social environ- } \\
\text { ment / Društveno } \\
\text { okružje }\end{array}$ & 0.40444 & 0.49189 & 0.42326 & 0.71654 & 1.00000 & 1.40000 & 0.52000 & 0.53216 & 0.49727 & 1.21333 \\
\hline Water / Voda & 0.28889 & 0.35135 & 0.30233 & 0.51181 & 0.71429 & 1.00000 & 0.37143 & 0.38012 & 0.35519 & 0.86667 \\
\hline Tax / Porez & 0.77778 & 0.94595 & 0.81395 & 1.37795 & 1.92308 & 2.69231 & 1.00000 & 1.02339 & 0.95628 & 2.33333 \\
\hline $\begin{array}{l}\text { Construction } \\
\text { cost / Troškovi } \\
\text { izgradnje }\end{array}$ & 0.76000 & 0.92432 & 0.79535 & 1.34646 & 1.87912 & 2.63077 & 0.97714 & 1.00000 & 0.93443 & 2.28000 \\
\hline $\begin{array}{l}\text { Transportation } \\
\text { Transport }\end{array}$ & 0.81333 & 0.98919 & 0.85116 & 1.44094 & 2.01099 & 2.81538 & 1.04571 & 1.07018 & 1.00000 & 2.44000 \\
\hline $\begin{array}{l}\text { Security } \\
\text { Sigurnost }\end{array}$ & 0.33333 & 0.40541 & 0.34884 & 0.59055 & 0.82418 & 1.15385 & 0.42857 & 0.43860 & 0.40984 & 1.00000 \\
\hline Total / Ukupno & 6.72000 & 8.17297 & 7.03256 & 11.90551 & 16.61538 & 23.26154 & 8.64000 & 8.84211 & 8.26230 & 20.16000 \\
\hline
\end{tabular}


Table 10 Determination of factor loads

Tablica 10. Određivanje opterećenosti kriterija

\begin{tabular}{|c|l|c|}
\hline No & \multicolumn{1}{|c|}{ Factors / Kriteriji } & $\begin{array}{c}\text { Value } \\
\text { Vrijednost }\end{array}$ \\
\hline 1 & Raw material / sirovina & 0.148809524 \\
\hline 2 & Labor force / radna snaga & 0.122354497 \\
\hline 3 & Market / tržište & 0.142195767 \\
\hline 4 & Energy and fuel / energija i gorivo & 0.083994709 \\
\hline 5 & $\begin{array}{l}\text { Social environment } \\
\text { društveno okružje }\end{array}$ & 0.060185185 \\
\hline 6 & Water / voda & 0.042989418 \\
\hline 7 & Tax / porez & 0.115740741 \\
\hline 8 & $\begin{array}{l}\text { Construction cost } \\
\text { troškovi izgradnje }\end{array}$ & 0.113095238 \\
\hline 9 & Transportation / transport & 0.121031746 \\
\hline 10 & Security / sigurnost & 0.049603175 \\
\hline & Total / Ukupno & 1.000000000 \\
\hline
\end{tabular}

Table 11 Results matrix

Tablica 11. Matrica rezultata

\begin{tabular}{|l|c|c|}
\hline $\begin{array}{l}\text { Candidate cities } \\
\text { Gradovi kandidati }\end{array}$ & $\begin{array}{c}\text { Results } \\
\text { Rezultati }\end{array}$ & $\%$ \\
\hline BOLU & 0.220791 & 22.08 \\
\hline KASTAMONU & 0.205971 & 20.60 \\
\hline KARABÜK & 0.200452 & 20.05 \\
\hline ZONGULDAK & 0.192778 & 19.28 \\
\hline BARTIN & 0.180007 & 18.00 \\
\hline
\end{tabular}

The loads of the factors have been identified as shown in Table 10 by conducting similar processes as in step 2 and 3.

\section{Step 4:}

After multiplying the last two matrixes, the values indicate which city stands out in the selection of the factory location (Table 11).

It has been determined, with $22.08 \%$, that it would be most appropriate to establish the planned timber factory in Bolu.

\section{DISCUSSION AND CONCLUSION} 4. RASPRAVA I ZAKLJUČAK

It is clearly stated in the literature that multicriteria decision making techniques and the results obtained using AHP are more effective when used together (Kurttilaa et al., 2000; Gürbüz et al., 2013; Okello et al., 2014). The aim of this study was to show that the result is more effective when combining the dual scaling method, which is a more subjective method, with AHP.

Considering the results of dual scaling, Bolu is a good option for the timber factory planned to be established with the value of $546.99(23.25 \%)$. Bolu has ranked first with $0.2208(22.08 \%)$ as a result of the evaluation via AHP.

It can be seen that Bolu achieved this result based on some important factors such as raw material, labor force and market. It is striking that both methods used in the study gave similar results. It is understood in the evaluation method that Bolu is proceeding with 22.66 $\%$ compared to other cities, where both methods were averaged (Table 12).

Although the ranking seems the same resulting from both methods, the increase in Zonguldak, Karabük and Kastamonu stands out, while there is a decrease in Bolu and Bartin according to the AHP method. The increase is especially dramatic and remarkable in Zonguldak and Karabük.

A similar result arising from the evaluation of the candidate cities appears in the comparison of the loads. The anticipated loads for the factors that will determine the location are such as to affect the results directly. The most important factor in dual scaling method, raw material, is the factor having the highest weight (0.1488) in accordance with AHP. The factor having the lowest weight, Water, has the lowest weight in AHP method with 0.0429 .

It is very important to go through the details again before selecting the timber factory location. All the alternatives must be assessed before determining the location where large-scale factories, requiring large investments, will be established. As a result of this study, applying the AHP method after the implementation of dual scaling method will cause the planners check their point of view. Such evaluation will provide reconsideration of the factors regarded as less important.

This study will provide a different viewpoint for the selection of timber factory location. This approach has been applied for the first time in this area. By taking the average of the results obtained by these two methods at the end of the study, the evaluation according to these data will lead the decision makers to make decisions in a more reliable way.

The results of this study show that not only can the timber factory location be selected, but in other areas it can be used to determine the factory location. The location of the paper mill, fiberboard mill and chipboard mill can also be selected.

Table 12 Comparison of the results obtained by two methods and hybrid method

Tablica 12. Usporedba rezultata dobivenih zasebnom primjenom metode odlučivanja i hibridne metode

\begin{tabular}{|l|c|c|c|c|c|}
\hline \multirow{2}{*}{$\begin{array}{c}\text { Candidate cities } \\
\text { Gradovi kandidati }\end{array}$} & \multicolumn{2}{c|}{$\begin{array}{c}\text { Dual Scaling } \\
\text { Dvostruko skaliranje }\end{array}$} & \multicolumn{2}{c|}{ AHP } & $\begin{array}{c}\text { Hybrid method } \\
\text { Hibridna metoda }\end{array}$ \\
\cline { 2 - 6 } & Value / Vrijednost & $\%$ & Value / Vrijednost & $\%$ & $\%$ \\
\hline BARTIN & 434.93 & 18.48 & 0.180007 & 18.00 & 18.24 \\
\hline BOLU & 546.99 & 23.25 & 0.220791 & 22.08 & 22.66 \\
\hline ZONGULDAK & 444.30 & 18.88 & 0.192778 & 19.28 & 19.08 \\
\hline KARABÜK & 447.72 & 19.03 & 0.200452 & 20.05 & 19.54 \\
\hline KASTAMONU & 479.07 & 20.36 & 0.205971 & 20.60 & 20.48 \\
\hline
\end{tabular}


Table 13 Comparison of factor loads by both methods

Tablica 13. Usporedba opterećenosti kriterija pri svakoj metodi odlučivanja

\begin{tabular}{|c|l|c|c|}
\hline \multirow{2}{*}{ No } & \multicolumn{1}{|c|}{ Factors / Kriteriji } & $\begin{array}{c}\text { Value (Dual Scaling) } \\
\text { Vrijednost (dvostruko skaliranje) }\end{array}$ & $\begin{array}{c}\text { Value (AHP) } \\
\text { Vrijednost (AHP) }\end{array}$ \\
\hline 1 & Raw material / sirovina & 10.0 & 0.148809524 \\
\hline 2 & Labor force / radna snaga & 8.0 & 0.122354497 \\
\hline 3 & Market / tržište & 9.5 & 0.142195767 \\
\hline 4 & Energy and fuel / energija i gorivo & 5.1 & 0.083994709 \\
\hline 5 & Social environment / društveno okružje & 3.3 & 0.060185185 \\
\hline 6 & Water / voda & 2.0 & 0.042989418 \\
\hline 7 & Tax / porez & 7.5 & 0.115740741 \\
\hline 8 & Construction cost / troškovi izgradnje & 7.3 & 0.113095238 \\
\hline 9 & Transportation / transport & 7.9 & 0.121031746 \\
\hline 10 & Security / sigurnost & 2.5 & 0.049603175 \\
\hline & Total / Ukupno & & \\
\hline
\end{tabular}

\section{REFERENCES}

\section{LITERATURA}

1. Barutçugil, İ., 1988: Production System and Management Techniques. Uludağ University Publication Number: 163, Bursa, Turkey.

2. Forman, E.; Gass, S., 2001: The analytic hierarchy process - An exposition. Operations Research, 49 (4): 469486. https://doi.org/10.1287/opre.49.4.469.11231

3. Golden, B.; Wasil, E.; Harker, P., 1989: The Analytic Hierarchy Process: Applications and Studies. Heidelberg, Germany: Springer-Verlag. https://doi.org/10.1007/978-3-642-50244-6

4. Gürbüz, T.; Albayrak, Y. E.; Alaybeyoğlu, E., 2013: Criteria Weighting and 4P's Planning in Marketing Using a Fuzzy Metric Distance and AHP Hybrid Method, 7 (1): 94-104. https://doi.org/10.1080/18756891.2014.853936

5. Ho, W., 2008: Integrated analytic hierarchy process and its applications - A literature review. European Journal of Operational Research, 186 (1): 211-228. https://doi.org/10.1016/j.ejor.2007.01.004

6. İlter, E., 2001: Preparation of Investment Projects, Evaluation and Monitoring, Bolu, Turkey.

7. Kainulainen, T.; Leskinen, P.; Korhonen, P.; Haara, A.; Hujala, T., 2009: A statistical approach to assessing interval scale preferences in discrete choice problems. Journal of the Operational Research Society, 60 (2): 252-258. https://doi.org/10.1057/palgrave.jors.2602554

8. Kobu, B., 1989: Production Management, Istanbul University, Faculty of Business Publication Number: 211, İstanbul, Turkey.

9. Kumar, S.; Vaidya, O., 2006: Analytic hierarchy process: An overview of applications. European Journal of Operational Research, 169 (1): 1-29. https://doi.org/10.1016/j.ejor.2004.04.028

10. Kurttilaa, M.; Pesonena, M.; Kangasb, J.; Kajanusa, M., 2000: Utilizing the analytic hierarchy process (AHP) in SWOT analysis - a hybrid method and its application to a forest-certification case. Forest Policy and Economics, 1 (1): 41-52. https://doi.org/10.1016/S1389-9341(99)00004-0

11. Liberatore, M.; Nydick, R., 2008: The analytic hierarchy process in medical and health care decision making: A literature review. European Journal of Operational Research, 189 (1): 194-207. https://doi.org/10.1016/j.ejor.2007.05.001

12. Okello, C.; Pindozzi, S.; Faugno, S.; Boccia, L., 2014: Appraising Bioenergy Alternatives in Uganda Using Strengths, Weaknesses, Opportunities and Threats
(SWOT) - Analytical Hierarchy Process (AHP) and a Desirability Functions Approach, Energies 2014, 7 (3): 1171-1192. https://doi.org/10.3390/en7031171

13. Saaty, T.; Forman, E., 1992: The Hierarchy Of: A Dictionary of Hierarchies. Pittsburgh, PA: RWS Publications.

14. Saaty, T., 1980: The Analytic Hierarchy Process, McGraw-Hill, New York.

15. Saaty, T., 1990: The Analytic Hierarchy Process in Conflict Management. International Journal of Conflict Management, 1 (1): 47-68. https://doi.org/10.1108/eb022672

16. Saaty, T., 1999: The Analytic Hierarchy Process for Decision Making, Kobe, Japan.

17. Saaty, T., 2000: Fundamentals of Decision Making and Priority Theory. RWS Publications, Pittsburgh, USA.

18. Shim, J., 1989: Bibliography research on the analytic hierarchy process (AHP). Socio-Economic Planning Sciences, 23 (3): 161-167. https://doi.org/10.1016/0038-0121(89)90013-X

19. Tam, M. C. Y.; Tummala, V. M. R., 2001: An Application of the AHP in Vendor Selection of a Telecommunications System. The International Journal of Management Science, 29 (2): 171-182. https://doi.org/10.1016/S0305-0483(00)00039-6

20. Üçüncü, K., 2003: Facilities Planning, Karadeniz Technical University, Faculty of Forestry Publication Number: 68, Trabzon, Turkey.

21. Vargas, L., 1990: An overview of the analytic hierarchy process and its applications. European Journal of Operational Research, 48 (1): 2-8.

https://doi.org/10.1016/0377-2217(90)90056-H

22. Zahedi, F., 1986: The analytic hierarchy process: A survey of the method and its applications. Interface, 16 (4): 96-108. https://doi.org/10.1287/inte.16.4.96

23. *** Anonymous, 1985: Preparation and Evaluation of Investment Projects. Research and External Relations Department, Ankara, Turkey.

\section{Corresponding address:}

Assoc. Prof. ALPER AYTEKIN, Ph.D.

Bartin University

Faculty of Economics and Administrative Sciences

Department of Management Information Systems

74100, Bartin, TURKEY

e-mail:aytekin@bartin.edu.tr 